\title{
On the Restrictive Jurisdictional Immunity of AIIB in China
}

\author{
Hu $\operatorname{Ren}^{1} \&$ Zhaoxin $\operatorname{Jin}^{1}$ \\ ${ }^{1}$ East China University of Science and Technology, Shanghai, China \\ Correspondence: Hu Ren, East China University of Science and Technology, Shanghai, China. E-mail: \\ yimhao@hotmail.com
}

Received: January 17, 2021

Accepted: February 19, 2021

Online Published: February 24, 2021

doi:10.5539/ilr.v10n1p185

URL: https://doi.org/10.5539/ilr.v10n1p185

\begin{abstract}
The jurisdictional immunity of international organizations is a necessity for them to independently perform their functions and achieve their purposes. Therefore, the international community generally grants absolute jurisdictional immunity to international organizations. China has always advocated the position of absolute jurisdictional immunity, however, in the AIIB Agreement and the Headquarters Agreement between China and AIIB, China turn to the view that AIIB only share restrictive jurisdictional immunity. The change of China's opinion on AIIB is not only the result of the development of international organizations immunity, but also the result of AIIB's functional necessity. The fact that AIIB only enjoys restrictive jurisdictional immunity in China makes AIIB possible to be sued in China's domestic courts. If the eligible plaintiff bring a lawsuit against AIIB in China, the courts could handle the case in accordance with domestic laws, the AIIB Agreement and the Headquarters Agreement to alleviate the dilemma of China's lack of international organization law.
\end{abstract}

Keywords: Asian Infrastructure Investment Bank, judicial jurisdiction, restrictive immunity, functional necessity

\section{Introduction}

On June 29, 2015, the Asian Infrastructure Investment Bank Articles of Agreement (AIIB Agreement) was formally signed. Then the AIIB was officially put into operation in December 2015. By the end of 2020, the AIIB has grown from 57 founding Members (37 regional and 20 non-regional) to 103 members, making it the second largest multilateral international financial institution only after the World Bank. While the achievements of the AIIB in terms of membership scale and investment financing are significant, the restrictive jurisdictional immunity of AIIB stipulated in the AIIB Agreement and the Headquarters Agreement between the Government of the People's Republic of China and the Asian Infrastructure Investment Bank (Headquarters Agreement) has aroused more attention.

Countries generally grant absolute immunity to international organizations (Pajuste, 2017), however, as the immunity of states shifts from absolute to restrictive, the immunity of international organizations also have some changes $(\mathrm{Li}, 2020)$. The absolute immunity of international organizations is still dominant, but its restrictive immunity has had more rationality (He\&Jiang, 2019). China basically insists on absolute immunity in the practice of foreign-related laws (He, 2015), and will not apply restrictive immunity to international organizations in the near future (Xie, 2014). The statement of the Ministry of Foreign Affairs of China and the judicial practice of China courts have shown that China still adheres to the absolute immunity position.

In practice, China has made some special provisions on the immunity of international financial organizations in China in some international treaties (Zhang\&Deng, 2015). Similarly, AIIB has also made some special provisions in its basic articles and adopted the position of restrictive immunity on the issue of state immunity (Mo\&Chen, 2016). The immunity exemptions in AIIB Agreement include four types of exemptions, which are intersecting and related to each other ( $\mathrm{Gu}, 2019)$, this article only researches the restrictive immunity on AIIB itself. Article 46 of the AIIB Agreement ${ }^{1}$ and Article 4 of the Headquarters Agreement ${ }^{2}$ show that AIIB might only share restrictive immunity in China.

The contradiction between the AIIB's restrictive jurisdictional immunity in China and China's official absolute

\footnotetext{
${ }^{1}$ Asian Infrastructure Investment Bank Articles of Agreement, Article 46, 29 June 2015.

${ }^{2}$ Headquarters Agreement between the Government of the People's Republic of China and the Asian infrastructure Investment Bank, Article 4, 16 January 2016.
} 
jurisdictional immunity position on international organizations leads to a series of thinking. In what situations does the AIIB only share restrictive jurisdictional immunity in China? Why the Chinese government signed the AIIB Agreement and the Headquarters Agreement that is different from its traditional position? How applicable the AIIB's restrictive jurisdictional immunity clause in China's domestic judicial practice is? This article intends to research the AIIB's restrictive jurisdictional immunity in China via analyzing the above issues, so as to provide a reference for solving other international organizations' jurisdictional immunity issue in China.

\section{China's International Organizations' Jurisdictional Immunity Practices and Changes in the AIIB Agreement}

\subsection{China's Practice of Jurisdictional Immunity of International Organizations}

Different from countries like Britain and the United States, China has no laws or regulations directly stipulating the immunity of states or international organizations. Generally, the theory of state immunity and its practice would influence the development and practice of international organizations' immunity. Therefore, China's position on immunity of international organizations could somehow be inferred from China's international practice of state immunity. Apart from that, China's position on the international organizations' immunity can also be inferred from the international treaties which China has signed and the judicial practice of international organizations in China's domestic courts.

In 1979, the US District Court of Alabama made a default judgment against China in Russell Jackson v. People's Republic of China. ${ }^{3}$ In February 1983, then-Foreign Minister Wu Xueqian submitted a memorandum of protest to the United States over the case, which clearly stated that China, as a sovereign state, should be exempt from the jurisdiction of the domestic courts of the United States. ${ }^{4}$ In 2008, China's court first accepted a case concerning state immunity. In the case of Democratic Republic of the Congo and others v. FG Hemisphere associates LLC, The Hong Kong Court of Final Appeal viewed that Hong Kong's position on state immunity should the same as the central government's view, so it submit to the standing committee of the National People's Congress. After the issue was interpreted, the final judgment was made on September 8, 2011, stating that the courts of Hong Kong have no jurisdiction over this case since Congo is a sovereign country. ${ }^{5}$ The above-mentioned typical judicial practices all show that China insists on absolute state sovereignty immunity.

Besides, when China joined international organizations, it always insisted on international organizations' absolute jurisdictional immunity. As the founding country and charter depository of the Shanghai Cooperation Organization, the Charter of the Shanghai Cooperation Organization may show China's attitude to some extent. Article 19 of the Charter clearly stipulates that Shanghai Cooperation Organization enjoy the immunities necessary for fulfilling its functions and achieving its goals which often be considered to enjoying absolute immunity. ${ }^{6}$ In addition, China's domestic courts seldom accept the case in which international organizations are brought lawsuit against, cases relevant to international organizations' jurisdictional immunity are even rarer. In Li Xiaobo v. Red Cross Representative Office in East Asia, the Supreme People's Court made a reply to the immunity issue involved in the case, in which it was clearly stated that as an international organization, the Red Cross representative office in east Asia shall enjoy absolute immunity and made a definitive reply that the case should not be accepted. ${ }^{7}$ Later, in 2014, in Zhu Zhu v. International Committee of the Red Cross, Beijing No.3 Intermediate People's Court also followed the position in reply of the Supreme People's Court made in 2009 and ruled that the International Committee of the Red Cross enjoys immunity from jurisdiction in China. ${ }^{8}$ The above cases all show that Chinese courts generally choose to grant absolute jurisdictional immunity to international organizations in judicial practice.

In summary, China's traditional practice is to grant international organizations an absolute jurisdictional immunity in China.

\subsection{Changes of AIIB's Jurisdictional Immunity in China}

The AIIB agreement stipulates the exceptions of absolute jurisdictional immunity, in the countries where AIIB has an office, or has appointed an agent to receive the subpoena or notice, or have issued or guaranteed bonds, the

\footnotetext{
${ }^{3}$ Russell Jackson v. People's Republic of China, 550 F.Supp.869 (N.D.Ala.1982).

${ }^{4}$ Zhou Zhonghai (2007). International Law. Beijing, China University of Political Science and Law Press, p.144.

${ }_{5}^{5}$ Democratic Republic of the Congo and others v. FG Hemisphere associates LLC, FACV 7/2010 (8 June 2011).

${ }^{6}$ Charter of the Shanghai Cooperation Organization, Article 19, U.N.T.S.2896, 1 February 2013.

${ }^{7}$ Reply of the Supreme People's Court to the Request for Instructions on Issues concerning Immunities in the Case of Disputes over a House Lease Contract between Li Xiaobo and the Regional Delegation for East Asia of the International Committee of the Red Cross, No. 25 [2009] of the Civil Division IV of the Supreme People's Court, 14 October 2009.

${ }^{8}$ Zhu Zhu v. International Committee of the Red Cross, No.06823 (2014) of Beijing No.3 Intermediate People's Court, 18 March 2015.
} 
AIIB might only have restrictive immunity in some situations. In addition, Article 52 of the AIIB Agreement also provides for the waiver of immunity, which enables the AIIB to waive its jurisdictional immunity so as to enter into judicial proceedings. In the case of restrictive immunity exceptions and the AIIB's waiver of immunity, the AIIB will no longer enjoy jurisdictional immunity and may become a defendant in a lawsuit and proceeded in cases.

First, the AIIB only enjoys restrictive jurisdictional immunity. As stipulated in Article 46.1, AIIB enjoy immunity from any form of legal procedures, except in cases arising from or exercising their power to raise funds, through borrowing or other means, guarantee obligations, buying and selling or underwriting the sale of securities. ${ }^{9}$ The clause lists the exceptional situations of the AIIB enjoying jurisdictional immunity, that is, except for the exceptional situations related to the exercise of power in the form of borrowing for the purpose of financing, AIIB enjoys jurisdictional immunity in member states.

Second, the AIIB's eligibility as a defendant is limited. As analyzed above, according to Article 46.1 of the AIIB Agreement, only when the bank meets the restricted circumstances, the AIIB as a defendant in eligible countries domestic court being sued become possible. It should also be noted that the case is caused by the bank's exercise of power to raise funds, rather than the result of functional actions such as encouraging public and private entities to invest or finance.

Third, the subject of eligible plaintiffs who sue the AIIB is limited. According to Article 46.2 of the AIIB Agreement, even if the facts of the case meet the exceptions of absolute judicial immunity listed in Article 46.1, some entities are still not allowed to bring a lawsuit against the AIIB, but to adopt other special procedures to resolve disputes. These clearly listed restricted subjects include any member, or any agency or instrumentality of a member, or any entity or person directly or indirectly acting for or deriving claims from a member or from any agency or instrumentality of a member. ${ }^{10}$ It excludes subjects in the sense of public law, making the eligible plaintiffs who may sue the AIIB limited to private subjects. Thereafter, it has been clearly stipulated that individuals who can represent members or member institutions, and individuals who obtain creditor's rights from members or member institutions shall not sue the bank, further narrowing the scope of private entities that can sue.

Fourth, the AIIB can waive jurisdictional immunity. According to Article 52 of the AIIB Agreement, banks may waive jurisdictional immunity in any case or instance, provided that such waivers are deemed to be in the bank's interest. ${ }^{11}$ In a broad sense, restrictive immunity generally includes the waiver of immunity. However, in a strict sense, the initiative to waive immunity is in the hands of international organizations, private victims cannot directly initiate litigation against international organizations based on the waiver of immunity clause, nor can the courts directly apply the clause to the jurisdiction of international organizations, so the article 52 would not be the AIIB's restrictive jurisdictional immunity clause.

The international organizations immunities have a dual nature of international nature and domestic nature. ${ }^{12}$ In law practice, they mainly manifested in the legal status of international organizations in a state. The domestic legal status of international organizations in a state depends on the legislation and practice of the domestic laws of each country. ${ }^{13}$ Therefore, the analysis of the AIIB's jurisdictional immunity in China also needs to be combined with China's international organizations practice. In general, intergovernmental international organizations have international legal status and are qualified to conclude treaties and agreements. ${ }^{14}$ As an intergovernmental international organization, Article 45 of the AIIB Agreement also stipulates that the AIIB has a complete legal personality, and has complete legal capabilities such as signing contracts, taking other necessary or useful actions to achieve its purpose and carry out activities. ${ }^{15}$ While the constitutional document AIIB agreement issues the main principles of AIIB, AIIB and China signed an agreement on January 16, 2016 to further define the legal status, privileges and immunities of the operation and function of AIIB in China. ${ }^{16}$

Article 4 of the Headquarters Agreement provides a total of five situations where immunity does not apply. Like the AIIB Agreement, this article stipulates two situations, civil litigation arising from or related to its power to

\footnotetext{
${ }^{9}$ AIIB Agreement, Article 46.1.

${ }^{10}$ Ibid, Article 46.2.

${ }^{11}$ Ibid, Article 52.

${ }^{12}$ August Reinisch (2000). International Organization before National Courts. Cambridge, Cambridge University Press, p.127.

${ }^{13}$ Xie Haixia (2012). On Immunity of the International Organization in National Courts. Journal of Beijing Administration Institute, (5), p.95.

${ }^{14}$ Ibid, p.94.

15 AIIB Agreement, Article 45.

${ }^{16}$ Headquarters Agreement, Preamble.
} 
raise funds through borrowing or other means and the waiver of immunity, but Article 18 of the Headquarters Agreement provides more detailed regulations on the circumstances in which the AIIB shall waive its jurisdictional immunity in China. ${ }^{17}$ Firstly, the purpose of waiving is for the interests of the AIIB rather than the personal interests of the relevant personnel and other factors. Secondly, the subject who has the right to waive the jurisdictional immunity of the AIIB is the board of directors. Finally, the waiver of immunity require specific circumstances where the board considers it appropriate to waive the immunities conferred by the Headquarters Agreement to be in the best interest of the Bank.

In addition to the above circumstances, the Headquarters Agreement added three additional circumstances for the AIIB's jurisdictional immunity in China, namely, the effect of the arbitration agreement, the compensation for vehicle traffic accidents, and the counterclaim. Article 4.1.(c) of the Headquarters Agreement relates to the effects of arbitration agreements, which is similar to Article 17 of the UN Convention on Jurisdictional Immunities of States and Their Property, confirming the court's supervisory jurisdiction over foreign arbitration agreements. ${ }^{18}$ Article 4.1.(c) of the Headquarters Agreement confirms the court has jurisdiction over the arbitration expressly accepted by the AIIB, if the AIIB has already submitted the relevant disputes to arbitration, it shall not resort to the jurisdictional immunity for the implementation of the arbitration agreement. ${ }^{19}$ Article 4.1.(d) of the Headquarters Agreement involves the issue of compensation for traffic accidents, which is similar to Article 43 of the Vienna Convention on Consular Relations. ${ }^{20}$ If a vehicle owned by or used by the AIIB causes a traffic accident in China, and a third party files a complaint against the AIIB, the AIIB shall not claim immunity from jurisdiction. Article 4.1.(e) of the Headquarters Agreement relates to counterclaims, which is similar to Article 32.3 of the Vienna Convention on Diplomatic Relations ${ }^{21}$, and Article 45.3 of the Vienna Convention on Consular Relations ${ }^{22}$. For any counterclaim directly related to proceedings initiated by the AIIB, the AIIB shall not claim jurisdictional immunity. Consistent with the jurisprudence behind Article 9.1 of the UN Convention on Jurisdictional Immunities of States and Their Property ${ }^{23}$, if the AIIB brings a lawsuit in a state's court, it cannot claim any immunity in counterclaims directly related to its own proceedings. Because the AIIB waives jurisdiction immunity by filing the suit voluntarily, and the action that the AIIB asserting its immunity in the counterclaim of immunity would violate the principles of estoppel and fairness in international law.

In summary, different from China's traditional position and practice on the immunity of international organizations, the jurisdictional immunity clauses in the AIIB Agreement and the Headquarters Agreement both show that China takes a restrictive jurisdictional immunity attitude on AIIB.

\section{The Reasons for the Restrictive Jurisdictional Immunity in the AIIB Agreement}

China has always adopted an absolute immunity stance on the issue of jurisdictional immunity of international organizations. This absolute immunity principle is not only a mainstream theory, but also a consistent practice. Nowadays, China has turned to the attitude of restrictive immunity on the issue of the AIIB. The reason for China to sign the AIIB Agreement and the Headquarters Agreement is not only the influence of the development of the theory of restrictive immunity of states and international organizations, but also the requirement for the definition and implementation of the necessary functions of the AIIB.

\subsection{The Influence of the Development of the Theory of Restrictive Immunity of States and International Organizations}

After World War II, the socialist countries led by the former Soviet Union began to participate in international civil and commercial activities in the name of the state, the western countries also began to enter the private field such as finance, trade, production and transportation as the subject of civil and commercial affairs, and intervened in the international private market. In order to protect the state's interests and national interests, western countries put forward the theory of state restrictive immunity. From that time, state sovereign immunity has developed from absolute to restrictive, which is not only embodied in legal theory but also in international judicial practice and many legal documents. Europe's exploration of the theory of state restrictive immunity originated from the European Convention on State Immunity, as the first international convention that stipulates immunity of states, it

\footnotetext{
${ }^{17}$ Ibid, Article 18.

${ }^{18}$ United Nations Convention on Jurisdictional Immunities of States and Their Property, Article 17, A/RES/59/38, 2 December 2004.

${ }^{19}$ Headquarters Agreement, Article 4.1. (c).

${ }^{20}$ Vienna Convention on Consular Relations, Article 43, 596 U.N.T.S.261, 24 April 1963.

${ }^{21}$ Vienna Convention on Diplomatic Relations, Article 32.3, 500 U.N.T.S.95, 18 April 1961.

${ }^{22}$ Vienna Convention on Consular Relations, Article 45.3.

${ }^{23}$ UN Convention on Jurisdictional Immunities of States and Their Property, Article 9.1.
} 
paved the way for the legislation on restrictive immunity of states, providing for exceptions to immunity from national jurisdiction from Article 1 to $13 .{ }^{24}$ The United Nations Convention on Jurisdictional Immunities of States and Their Property made a leap forward, which confirmed the theory of restrictive jurisdictional immunity of states, stipulating eight exceptions or limitations of jurisdictional immunity from Articles 10 to 17. In addition, domestic legislation also has relevant practices. In the Foreign Sovereign Immunity Act of 1976, the United States listed seven situations in which foreign state immunity is not applicable to foreign state immunity ${ }^{25}$, it formally and explicitly stipulated the restrictive situation of state immunity, and incorporated restricted immunity into the domestic legal system.

When international organizations came into being, their independent legal status was not recognized, but regarded as a collection of states, all countries tended to apply the principle of state immunity to them directly at that time. ${ }^{26}$ In the whole process of formation and development of the international organization immunity legal system, it is difficult to ignore the influence of the state immunity theory. Taking the International Organization Immunity Act of the United States as an example, it stipulates that international organizations enjoy the same immunity from suit and any form of the judicial procedure as foreign governments. ${ }^{27}$ Similarly, some of the constitutional documents and international treaties signed by international organizations of the international community directly stipulate that the international organization enjoys the same immunity as a state. For example, Article 3 of the Headquarters Agreement Between the Government of Canada and the International Civil Aviation Organization clearly stipulates that the International Civil Aviation Organization shall enjoy the same litigation immunity and various forms of judicial process immunity as foreign countries. ${ }^{28}$ Although the AIIB Agreement does not stipulate that the AIIB enjoys the same jurisdictional immunity as foreign governments, the exceptions of the AIIB's jurisdictional immunity stipulated in the Headquarters Agreement reflect the impact of the development of state's restrictive immunity.

First of all, Article 4.1.(c) of the Headquarters Agreement on the enforcement of the exemption exception to the arbitration agreement reflects a generally accepted principle of state immunity, that is, a country's acceptance of commercial arbitration is equivalent to agreeing to jurisdiction over the arbitration agreement. ${ }^{29}$ Secondly, the Article 4.1.(d) of the Headquarters Agreement is not only the development of Article 43 of the Vienna Convention on Consular Relations, but also related to the resolutions of the UN General Assembly. Because of the frequent occurrence of traffic accidents, in order to reduce the influence of the traffic accident on the implementation of the function of international organization, the United Nations General Assembly passed a resolution in 1946, requiring international organizations affiliated to the United Nations to purchase vehicle insurance. If traffic accidents occur during the performance of their functions, the United Nations organization allows insurance companies deal with it in accordance with local laws and the international organization could not claim jurisdictional immunity in relevant civil lawsuits. ${ }^{30}$ Finally, Article 4.1.(e) of the Headquarters Agreement stipulates that the AIIB cannot claim jurisdictional immunity for any counterclaim directly related to its own litigation procedures, since direct counterclaim doesn't enjoy immunity as early as stipulated in the state's immunity treaty ${ }^{31}$, the rules directly reflects the state restrictive immunity theory's influence on the theory of international group limited waivers.

In short, the development and establishment of the theory of state restrictive immunity promoted the development and maturity of the theory of international organizations' restrictive immunity, which affected and contributed to the AIIB's position of adopting restrictive immunity in its agreement.

\subsection{The Requirements of Necessary Functions of the AIIB}

The theory of functional necessity is the mainstream theory of international organization immunity, it believes that

\footnotetext{
${ }^{24}$ European Convention on State Immunity, Article 1-13, ETS No.074, 16.V.1972.

${ }^{25}$ Foreign Sovereign Immunities Act of 1976, Article 1605, 28.U.S.C., 21 October 1976.

${ }^{26}$ Li Zan (2012). On the Relationship between Immunity of International Organizations and Sovereign Immunity. Journal of Yunnan University (Law Edition), (5), p.103.

${ }^{27}$ International Organizations Immunities Act of 1945, Article 288, 22 U.S.C., 29 December 1945.

${ }^{28}$ Headquarters Agreement between the Government of Canada and the International Civil Aviation Organization, Article 3, E101905-CTS 1992 No.7, 14 April 1951.

${ }^{29}$ Ma Xinmin (2005). Review of the United Nations Convention on Jurisdiction Immunity of States and Their Property. The Jurist, (6), p.6.

${ }^{30}$ The Secretary-General: Report of the Secretary-General on Procedures in Place for Implementation of Article VIII, Section 29, of the Convention on the Privileges and Immunities of the UN, adopted by the General Assembly on 13 February 1946, para.14, U.N.Doc.A/C.5/49/65 (24 April 1995).

${ }^{31}$ He Zhipeng \& Jiang Chenxi (2019). Theoretical Analysis and Practical Position on the Restrictive Immunity of International Organizations. Pacific Journal, (7), p.8.
} 
if an international organization enjoys immunity, it can be independent from external influences, thereby ensuring that the international organization can perform its functions independently. ${ }^{32}$ Since the functional necessity theory is used as the criterion to determine the immunity of international organizations, the immunity is bound to be limited by organization's functions. ${ }^{33}$ Generally the relationship between the functions and immunity of the AIIB is "if and only if". It is necessary for AIIB to obtain jurisdictional immunity if and only if it is necessary for AIIB to perform its functions. Different from the division of national acts according to commercial, the scope of functional acts of international organizations is defined by organizational documents and practices. Therefore, the purpose and functions of the AIIB must be determined in conjunction with specific treaties or agreements, and be determined on this basis whether immunity should be granted.

The constitutional documents of international organizations often provide general provisions for their own purposes and functions. The preamble of the AIIB Agreement states that as an international financial institution, the AIIB aims to cooperate and supplement existing multilateral development banks to promote sustained and stable growth in Asia. ${ }^{34}$ Article 1 of the AIIB Agreement clearly states that the AIIB hopes to promote the sustainable development of the Asian economy through investment in infrastructure, and to respond to various challenges through close cooperation with other development institutions. ${ }^{35}$ In order to fulfill its purpose, Article 2 of the AIIB Agreement further stipulates the AIIB's functions of promoting public and private capital investment in the region, providing financing support for regional development with disposable funds, and encouraging private capital to participate in the investment. ${ }^{36}$ As can be seen from the articles of the AIIB Agreement, AIIB's functions are to fulfill its purpose by promoting capital investment, providing financing support and encouraging private capital investment.

Functional necessity can be understood as necessary to perform functions independently. ${ }^{37}$ Functionally necessary acts only refer to behaviors necessary for independent performance of functions. Therefore, not all acts of international organizations are functionally necessary. Article 16 of the AIIB Agreement stipulates the general powers of the AIIB to raise funds, guarantee debts, buy and sell or underwrite claims, and manage trust funds. ${ }^{38}$ It points out that the AIIB may also exercise other appropriate powers necessary to further realize its purpose and functions. The regulations indicate that the AIIB's actions to raise funds through debt or other means are also out of the need to achieve its purpose and functions. However, through analysis of the AIIB's functions, it can be found that the actions of raising funds are not to promote capital investment, financing support, encouraging private capital investment behavior, nor to strengthen these functions to carry out other activities and provide other services, therefore, the right to raise debt guarantee rights, the act of buying and selling or underwriting bonds is not necessary for functions to perform. For actions that are not necessary for functions, the AIIB should not enjoy jurisdictional immunity. Therefore, Article 46 of the AIIB Agreement lists circumstances in which the AIIB exercises these general powers through loans and other forms as exceptions. This shows that the above situations are not necessary for the AIIB to perform its functions.

\section{Analysis on the Application of AIIB's Restrictive Jurisdictional Immunity in China}

Both the AIIB Agreement and the Headquarters Agreement indicate that the AIIB only enjoys restrictive jurisdictional immunity, and the AIIB shall not claim jurisdictional immunity for certain exceptional circumstances. As an intergovernmental international organization headquartered in China, the operation of the AIIB is not only subject to international law and but also to Chinese law, therefore, it brings new challenges to Chinese law, China's courts, and absolute jurisdictional immunity of international organizations under Chinese law. ${ }^{39}$

Article 46.1 of the AIIB Agreement lists the courts that can bring a lawsuit against the AIIB. In countries where AIIB has offices, or where an agent has been entrusted to receive notice of service or procedure, or where securities have been issued or secured, eligible plaintiffs can file a lawsuit in a court with jurisdiction. ${ }^{40}$ The Asia Financial

\footnotetext{
${ }^{32}$ C.T.Oliver et al., (1995). The International Legal System: Cases and Materials. New York, The Foundation Press, p.613.

${ }^{33} \mathrm{Li}$ Zan (2013). On the Determination of the Official Act of an International Organization - The Prerequisite for the Immunity of International Organization. Journal of Yunnan University (Law Edition), (4), p.134.

${ }^{34}$ AIIB Agreement, Preamble.

${ }^{35}$ Ibid, Article 1.

${ }^{36}$ Ibid, Article 2.

${ }^{37}$ Li Zan (2011). On the Theoretical Basis for Immunity of International Organizations. Northern Legal Science, (3), p.121.

${ }^{38}$ AIIB Agreement, Article 16

${ }^{39}$ Mo Shijian \& Chen Shi (2016). Conflict and Coordination in State Immunity under AIIB Agreement and Chinese Law. Journal of Political

Science and Law, (1), p.30.

${ }^{40}$ AIIB Agreement, Article 46.1.
} 
Tower in Beijing, China is the permanent office building of the AIIB headquarter, so China meets the first situation listed, namely the country where the AIIB has an office. Therefore, the plaintiff who meets the qualifications can bring a lawsuit in China to a competent court with sufficient jurisdiction. When the plaintiff brings a lawsuit against the AIIB in China, it shall decide whether it is a major foreign-related case and select the court level according to the provisions of the Civil Procedure Law of the People's Republic of China (Civil Procedure Law), and then bring a lawsuit in a qualified court.

For civil cases involving immunities, the Notice of the Supreme People's Court on Issues Concerning the Acceptance of Civil Cases Involving Privileges and Immunities establishes a reporting system, if the defendant or third party of the case is one of the twelve situations listed in the notice, the notice shall be applied. ${ }^{41}$ Although the notice clearly lists only one international organization, the United Nations representative office in China, the AIIB can also be included in the twelfth item "other entities enjoying privileges and immunities in China". Therefore, if the plaintiff brings a lawsuit against the AIIB in China's court according to the AIIB Agreement and the Headquarters Agreement, the case should be reported to the higher people's court under the jurisdiction of the place for review. If the higher people's court agrees to accept the lawsuit, it shall submit its review opinion to the Supreme People's Court. The court that accepts the plaintiff's suit shall temporarily dismiss it until it receives a reply from the Supreme People's Court.

It is difficult for the Supreme People's Court to give an affirmative answer to the civil cases in which AIIB is the defendant based on the reporting system, however, it is possible to get a glimpse of it in an analysis based on the relevant provisions of the Civil Procedure Law. First, according to Article 522 of the Interpretation of the Supreme People's Court on the Application of the Civil Procedure Law of the People's Republic of China, it can be determined that the civil lawsuit filed against the AIIB is a foreign-related civil case. ${ }^{42}$ Then, in accordance with Article 259 of the Civil Procedure Law, the special provisions on foreign-related civil litigation procedures in Part IV of the Civil Procedure Law shall apply to civil actions involving international organizations as defendants. ${ }^{43}$ Finally, Article 261 of the Civil Procedure Law stipulates that civil lawsuits brought against international organizations enjoying immunities shall be subject to relevant Chinese laws or international treaties concluded or acceded to by China ${ }^{44}$, so civil lawsuits filed against the AIIB should be handled in accordance with relevant Chinese laws and international treaties. Regarding the application of Chinese law or international treaties, Article 260 of the Civil Procedure Law stipulates the priority application of international treaties, but it does not provide for the jurisdictional immunity of international organizations. ${ }^{45}$ Therefore, the Jurisdictional immunity of AIIB will be judged according to the AIIB Agreement and the Headquarters Agreement. If the plaintiff filed a civil lawsuit against the AIIB in a Chinese court in accordance with several circumstances stipulated in the AIIB Agreement and the Headquarters Agreement, and the plaintiff does not fall within the scope of the subject limited by the two agreements, AIIB would only have restrictive jurisdictional immunity, China's court does have jurisdiction over this case.

After determining that the Chinese courts have jurisdiction over AIIB, qualified private entities can sue AIIB in China, but the specific choice of law for foreign-related civil legal relations needs to be combined with the plaintiff's claims. When the plaintiff sues in accordance with Article 4.1(a) of the Headquarters Agreement, the court should select the applicable law in accordance with the Law of the Application of Law for Foreign-related Civil Relations of the People's Republic of China (Law of Application Law) in light of the specific circumstances. If the plaintiff filed a lawsuit in accordance with Article 4.1.(b) of the Headquarters Agreement, the court shall apply the applicable law selected by the parties through agreement in accordance with Article 41 of the Law of Application Law. ${ }^{46}$ If the plaintiff filed a lawsuit in accordance with Article 4.1.(c) of the Headquarters Agreement, the court shall handle the enforcement of awards of foreign arbitration institutions of China or foreign arbitration institutions in accordance with Article 273 or Article 283 of the Civil Procedure Law. ${ }^{47}$ If the plaintiff filed a lawsuit in accordance with Article 4.1.(d) of the Headquarters Agreement, the court shall apply the law of a place

\footnotetext{
${ }^{41}$ Notice of the Supreme People's Court on the Relevant Issues concerning the People's Courts to Accept Civil Cases Involving Privilege and Immunity, No.60[2007] of the Supreme People's Court, 22 May 2007.

42 Interpretation of the Supreme People's Court on the Application of the Civil Procedure Law of the People's Republic of China, No.5 [2015] of the Supreme People's Court, 18 December 2014.

${ }^{43}$ Civil Procedure Law of the People's Republic of China, Article 259, 27 June 2017.

44 Ibid, Article 261.

${ }^{45}$ Ibid, Article 260

${ }^{46}$ Law of the Application of Law for Foreign-related Civil Relations of the People's Republic of China, Article 41, 28 October 2010.

47 Civil Procedure Law, Article 273, 283.
} 
of tortious act in accordance with Article 44 of the Law of Application Law. ${ }^{48}$ If the plaintiff filed a lawsuit in accordance with Article 4.1.(e) of the Headquarters Agreement, the people's courts shall conduct a combined trial in accordance with the Civil Procedure Law and in accordance with the applicable laws of the original lawsuit.

To sum up, although China's international organization law is not perfect, China cannot take the imperfect provisions in its domestic laws as the basis for not fulfilling its obligations under international law. ${ }^{49}$ By exploring the people's courts' reporting system of civil cases involving privileges and immunities, and analyzing China's domestic law (Civil Procedure Law and Law of the Application of Law) and international treaties (AIIB Agreement and the Headquarters Agreement), it can be found that the eligible plaintiff could sue the AIIB in China's domestic courts, the AIIB only enjoys restrictive jurisdictional immunity in China, the jurisdiction and trial of the AIIB defendants in China's domestic courts do have legal basis.

\section{Conclusion}

As a multilateral investment and development institution, the economic function is the most prominent function of the AIIB. According to Article 31 of the AIIB Agreement, the AIIB shall not interfere in the political affairs of any member in its decision-making, nor shall it be affected by the political characteristics of any member, and only consider economic factors in its decision-making. ${ }^{50}$ The credit of an economic international organization is closely related to the possibility of the organization being sued, and the credit of an international organization has a huge impact on its business development, function performance and purpose realization. ${ }^{51}$ Therefore, the adoption of restrictive jurisdictional immunity in the AIIB Agreement and the Headquarters Agreement is not only the result of the development of state's restrictive jurisdictional immunity theory and international organization's restrictive jurisdictional immunity theory, but also the result of AIIB's necessary economic functions such as promoting public and private capital investment and providing financing support.

Given that China has no legislation on the jurisdictional immunity of international organizations, the AIIB's restrictive attitude in AIIB Agreement and the Headquarters Agreement poses challenges to China's absolute position on international organizations' immunity. However, China is in no hurry to clearly express its attitude and position on the issue of international organizations' immunity. In practice, China can refer to the Headquarters Agreement and sign bilateral treaties with specific international organizations, so that when the eligible plaintiff filed a civil lawsuit against one certain international organization in a domestic court in China, the court can hear the case in accordance with existing domestic laws and regulations and bilateral agreements.

\section{References}

Asian Infrastructure Investment Bank Articles of Agreement, 29 June 2015.

August, R. (2000). International Organization before National Courts. Cambridge, Cambridge University Press. Charter of the Shanghai Cooperation Organization, U.N.T.S.2896,1 February 2013.

Civil Procedure Law of the People's Republic of China, 27 June 2017.

Democratic Republic of the Congo and others v. FG Hemisphere associates LLC, FACV 7/2010. (2011, June 8).

European Convention on State Immunity, ETS No.074, 16. V.1972. https://doi.org/10.1002/j.23338504.1972.tb00634.x

Foreign Sovereign Immunities Act of 1976, 28.U.S.C., 21 October 1976.

Gu, B. (2019). AIIB Immunity Study. BFSU Legal Science, (1).

He, Z. P. (2015). China's Position on Sovereign Immunity. Tribune of Political Science and Law, (3).

He, Z. P., \& Jiang, C. X. (2019). Theoretical Analysis and Practical Position on the Restrictive Immunity of International Organizations. Pacific Journal, (7).

Headquarters Agreement between the Government of Canada and the International Civil Aviation Organization, E101905-CTS 1992 No.7, 14 April 1951.

\footnotetext{
${ }^{48}$ Law of Application Law, Article 44.

${ }^{49}$ Kong Qingjiang \& Wang Yilin (2018). A New Perspective of the Relationship between International Law and Municipal Law: Legal Instruments of International Organizations. Wuhan University International Law Review, (1), p.54.

${ }^{50}$ AIIB Agreement, Article 31.

${ }^{51}$ Jan Klabbers (2015). The Transformation of International Organizations Law. The European Journal of International Law, (1), p.57.
} 
Headquarters Agreement between the Government of the People's Republic of China and the Asian infrastructure Investment Bank, 16 January 2016.

International Organizations Immunities Act of 1945, 22 U.S.C., 29 December 1945.

Interpretation of the Supreme People's Court on the Application of the Civil Procedure Law of the People's Republic of China, No.5 [2015] of the Supreme People's Court, 18 December 2014.

Jan, K. (2015). The Transformation of International Organizations Law. The European Journal of International Law, (1).

Kong, Q. J., \& Wang, Y. L. (2018). A New Perspective of the Relationship between International Law and Municipal Law: Legal Instruments of International Organizations. Wuhan University International Law Review, (1).

Law of the Application of Law for Foreign-related Civil Relations of the People's Republic of China, 28 October 2010.

Li, Z. (2011). On the Theoretical Basis for Immunity of International Organizations. Northern Legal Science, (3).

Li, Z. (2012). On the Relationship between Immunity of International Organizations and Sovereign Immunity. Journal of Yunnan University (Law Edition), (5).

Li, Z. (2013). On the Determination of the Official Act of an International Organization - The Prerequisite for the Immunity of International Organization. Journal of Yunnan University (Law Edition), (4).

Li, Z. (2020). Rediscover the Immunity of International Organizations in the View of National Interests from the Case of Jam, et al. v. International Finance Corp. Chinese Review of International Law, (2).

Ma, X. M. (2005). Review of the United Nations Convention on Jurisdiction Immunity of States and Their Property. The Jurist, (6).

Mo, S. J., \& Chen, S. (2016). Conflict and Coordination in State Immunity under AIIB Agreement and Chinese Law. Journal of Political Science and Law, (1).

Notice of the Supreme People's Court on the Relevant Issues concerning the People's Courts to Accept Civil Cases Involving Privilege and Immunity, No.60[2007] of the Supreme People's Court, 22 May 2007.

Oliver, C. T. et al. (1995). The International Legal System: Cases and Materials. New York, The Foundation Press.

Reply of the Supreme People's Court to the Request for Instructions on Issues concerning Immunities in the Case of Disputes over a House Lease Contract between Li Xiaobo and the Regional Delegation for East Asia of the International Committee of the Red Cross, No. 25 [2009] of the Civil Division IV of the Supreme People's Court, 14 October 2009.

Russell Jackson v. People's Republic of China, 550 F.Supp.869 (N.D.Ala. 1982).

The Secretary-General: Report of the Secretary-General on Procedures in Place for Implementation of Article VIII, Section 29, of the Convention on the Privileges and Immunities of the UN, adopted by the General Assembly on 13 February 1946, U.N.Doc.A/C.5/49/65. (24 April 1995).

Tiina Pajuste. (2017). The Evolution of the Concept of Immunity of International Organizations. East-West Studies, (8).

United Nations Convention on Jurisdictional Immunities of States and Their Property, A/RES/59/38, 2 December 2004.

Vienna Convention on Consular Relations, 596 U.N.T.S.261, 24 April 1963.

Vienna Convention on Diplomatic Relations, 500 U.N.T.S.95, 18 April 1961.

Xie, H. X. (2012). On Immunity of the International Organization in National Courts. Journal of Beijing Administration Institute, (5).

Xie, H. X. (2014). International Organization Jurisdictional Immunity: From Absolute Immunity to Restrictive Immunity. Journal of Political Science and Law, (5).

Zhang, C. L., \& Deng, X. Y. (2015). Privileges and Immunities of the International Developmental Financial Organizations. Journal of South China University of Technology (Social Science Edition), (2).

Zhou, Z. H. (2007). International Law. Beijing, China University of Political Science and Law Press. 
Zhu Zhu v. International Committee of the Red Cross, No.06823 (2014) of Beijing Third Intermediate People's Court, 18 March 2015.

\section{Copyrights}

Copyright for this article is retained by the author(s), with first publication rights granted to the journal.

This is an open-access article distributed under the terms and conditions of the Creative Commons Attribution license (http://creativecommons.org/licenses/by/4.0/). 